\title{
Effects of Angiotensin II Type 1 receptor blocker and adiponectin on adipocyte dysfunction in stroke-prone spontaneously hypertensive rats
}

\author{
Kumiko Takemori ${ }^{*}$, Takao Inoue ${ }^{2}$ and Hiroyuki Ito ${ }^{3}$
}

\begin{abstract}
Background: Hypoadiponectinemia in lipoatrophy may be related to worsening of hypertension in stroke-prone spontaneously hypertensive rats (SHRSP). One of the beneficial effects of candesartan (Angiotensin II Type 1 receptor blocker) for preventing hypertension may be increasing of adiponectin due to improvement of adipocyte dysfunction. In this study, we determined the effects of candesartan or adiponectin on pathophysiologic features and adipocyte dysfunction in SHRSP.

Methods: Candesartan was administered to male SHRSP from 16 to 20 weeks of age (2 mg/kg/day). Adiponectin was cloned and intravenously administered to male SHRSP from 16 to 20 weeks of age. We examined biological parameters, as well as the expression and release of adipokines.

Results: The SHRSP exhibited severe atrophy of visceral fat and progression of severe hypertension. The expression and release of leptin and adiponectin were impaired at 6 and 20 weeks of age. Candesartan suppressed the development of lipoatrophy and reduced the incidence of stroke at 20 weeks of age. Candesartan also enhanced the expression of adiponectin and leptin by inducing the overexpression of peroxisome proliferator activated receptor $\gamma$. Circulating level of leptin was significantly higher in candesartan group than in the control group, whereas adiponectin was similar in both groups. Intravenous administration of adiponectin resulted in enhancement of adiponectin expression in adipose tissue, but no remarkable effects were found in pathophysiology in SHRSP.

Conclusions: Our results indicate that candesartan protects against hypertension and adipocyte dysfunction in SHRSP. The induction of leptin expression appeared to be important factor in the inhibition of stroke lesions, whereas adiponectin was not a major regulator of blood pressure in SHRSP with genetic hypertension. Further studies are needed to elucidate the role of the renin-angiotensin system in adipose tissue dysfunction in relation to hypertensive end-organ damage.
\end{abstract}

Keywords: Stroke-prone spontaneously hypertensive rats, Adipose tissue, Renin-angiotensin system, Angiotensin II type I receptor blocker, Lipoatrophy, Adipokines

\section{Background}

As is well known, adipose tissue is a major endocrine system, and the abnormal expression of adipokines by hypertrophied adipocytes in obesity is involved in the pathogenesis of hypertension and vascular disorders [1]. On the other hand, an association between hypertension

\footnotetext{
* Correspondence: kuriman@nara.kindai.ac.jp

'Department of Food Science and Nutrition, Faculty of Agriculture, Kinki University 3327-204, Nakamachi Nara-City, Nara 631-8505, Japan Full list of author information is available at the end of the article
}

and lipoatrophy was also reported in patients infected with human immunodeficiency virus $[2,3]$ and in patients with familiar partial lipodystrophy (FPLD3) [3,4].

Stroke-prone spontaneously hypertensive rats (SHRSP), a well-established model of genetic hypertension, are lean and develop marked lipoatrophy with the progress of hypertension. Although several factors are involved in the pathogenesis of severe hypertension in SHRSP, lipoatrophy may be an important factor, because feeding these rats a high-fat high-cholesterol diet improved lipoatrophy,

\section{() Biomed Central}

(c) 2013 Takemori et al.; licensee BioMed Central Ltd. This is an Open Access article distributed under the terms of the Creative Commons Attribution License (http://creativecommons.org/licenses/by/2.0), which permits unrestricted use, distribution, and reproduction in any medium, provided the original work is properly cited. 
extended their life-span, and decreased the incidence of stroke (unpublished data). These results suggest that adipocyte dysfunction is related to hypertension in SHRSP. Moreover, A-ZIP/F-1 mice, an animal model of lipoatrophic diabetes, lack white adipose tissue and exhibit hypertension [5]. We previously reported that A-ZIP/F1 mice show higher blood pressure and enhanced agonist-induced arterial wall contractility compared with wild-type mice [6]. These findings suggest that adipose tissue may have an important role in the pathogenesis of hypertension in obesity and in lipoatrophy.

Since Engeli et al. [7] first reported that the reninangiotensin system (RAS) is localized in many tissues, including adipose tissue, many studies have been performed to examine the role of the RAS in adipose tissue in relation to adipocyte differentiation and hypertension. For example, Zorad et al. [8] investigated the effects of candesartan, an angiotensin II type I receptor blocker (ARB), on adipose tissue growth, and adipokine expression and release in normotensive non-obese Wistar-Kyoto rats (WKY). They reported that candesartan induced adipose tissue hypotrophy and increased the expression of adiponectin and peroxisome proliferator-activated receptor (PPAR) $\gamma$. We previously reported that early and transient treatment of SHRSP with low doses of candesartan prevented hypertensive end-organ damage $[9,10]$. The protective effects of ARBs against hypertension and its complications were clearly demonstrated in a comprehensive series of studies performed by Saavedra et al. [11-13]. Their and our findings suggest that these beneficial effects of ARB may be due to prolonged inhibition of the RAS in several tissues, including adipose tissue. However, the mechanisms involved in these effects of RAS inhibition were unclear.

In this study, we focused on the pathophysiological characteristics of visceral adipose tissue in SHRSP. As one of the beneficial effects of candesartan, we hypothesized that candesartan may improve circulatory disturbances in SHRSP by enhancing adiponectin production as a result of inhibiting the RAS in adipose tissue. To test this hypothesis, we treated SHRSP with either candesartan or adiponectin and determined the changes in blood pressure and adipocyte function.

\section{Results}

Comparison of adipocyte function between WKY and SHRSP We first assessed the adipokine expression profiles in WKY and SHRSP at 6 and 20 weeks of age. Table 1 shows the serum adipokine levels and mRNA expression in epididymal adipose tissue. At 6 weeks of age, the serum leptin and adiponectin levels were significantly lower in SHRSP than in WKY. Furthermore, the mRNA expression levels of leptin, adiponectin, and PPAR $\gamma$ were lower in SHRSP, consistent with the circulating levels. The circulating leptin and adiponectin levels were also lower in SHRSP than in WKY at 20 weeks of age. Although the mRNA expression level of leptin in epididymal fat tissue was significantly lower in SHRSP than in WKY, there were no significant differences in either adiponectin or PPARy mRNA expression levels between WKY and SHRSP. These results indicate that adipocyte dysfunction occurred before the onset of hypertension in SHRSP. Based on these findings, we conducted experiments to examine the effects of treating SHRSP with an ARB.

\section{Effects of candesartan on blood pressure, body weight, and cerebral lesions}

Table 2 presents the biological characteristics of 20-weekold SHRSP treated with or without candesartan. Blood pressure was significantly lower and body weight was significantly heavier in the candesartan-treated group than in the control group. The total visceral fat pad weight was significantly greater in the candesartantreated group than in the control group. By contrast, brain weight was significantly lower in the candesartantreated group than in the control group. Cerebral lesions (edema, softening, or hemorrhage) were found in $7 / 8$ rats $(87.5 \%)$ in the control group but in none in the candesartan-treated group.

\section{Effects of candesartan on adipokine expression}

As shown in Figure 1, plasma leptin levels were significantly higher in the candesartan group than in the control group, whereas serum adiponectin levels were similar in both groups. However, the mRNA expression levels of leptin, adiponectin, and PPAR $\gamma$ in adipocytes were significantly greater in the candesartan group than in the control group, as indicated in Table 3.

\section{Effects of intravenous adiponectin administration}

Table 4 shows the effects of continuous intravenous infusion of adiponectin in SHRSP. There were no significant differences in blood pressure or body weight between the adiponectin-treated group and the control group. Blood adiponectin levels were slightly, but not significantly, higher in the adiponectin-treated group than in the control group, whereas leptin levels were similar in both groups. The mRNA expression level of adiponectin in adipose tissue was significantly higher in the adiponectin-treated group than in the control group. However, the expression levels of adiponectin receptors (Adipo-R1, Adipo-R2, and cadherin 13) in skeletal muscle were not significantly different between the two groups.

\section{Discussion}

In the present study, we revealed that candesartan ameliorated not only hypertension but also lipoatrophy in SHRSP. One of the mechanisms of decreasing of 
Table 1 Circulating and mRNA expression levels of adipocyte-related molecules in WKY and SHRSP

\begin{tabular}{|c|c|c|c|c|}
\hline & \multicolumn{2}{|c|}{6 weeks of age } & \multicolumn{2}{|c|}{20 weeks of age } \\
\hline & WKY & SHRSP & WKY & SHRSP \\
\hline \multicolumn{5}{|c|}{ Serum adipokine levels } \\
\hline Leptin (ng/ml) & $2.895 \pm 0.700$ & $0.568 \pm 0.450$ & $9.003 \pm 0.673$ & $4.497 \pm 0.383^{* *}$ \\
\hline Adiponectin $(\mu \mathrm{g} / \mathrm{ml})$ & $11.559 \pm 1.037$ & $8.491 \pm 0.243^{* *}$ & $10.054 \pm 0.219$ & $5.934 \pm 0.222^{* *}$ \\
\hline \multicolumn{5}{|c|}{ Adipokine expression in epididymal adipocytes (ratio to $18 \mathrm{~S}$ rRNA) } \\
\hline Leptin & $1.059 \pm 0.098$ & $0.251 \pm 0.049^{* *}$ & $4.204 \pm 0.746$ & $2.012 \pm 0.177^{* *}$ \\
\hline Adiponectin & $1.045 \pm 0.070$ & $0.609 \pm 0.050^{*}$ & $1.301 \pm 0.108$ & $1.167 \pm 0.05$ \\
\hline PPARY & $1.010 \pm 0.086$ & $0.544 \pm 0.068^{*}$ & $0.517 \pm 0.038$ & $0.407 \pm 0.050$ \\
\hline
\end{tabular}

SHRSP: stroke-prone spontaneously hypertensive rats; PPARY: peroxisome proliferator-activated receptor $\gamma ;$ WKY: Wistar-Kyoto rats. Values are means \pm SE. ${ }^{*} \mathrm{p}<0.05$ and ${ }^{* *} \mathrm{p}<0.01$ vs. age matched WKY (Student's $t$-test).

blood pressure and lowering of stroke lesion may be due to improvement of adipocyte dysfunction.

Although angiotensin II was reported to inhibit adipocyte differentiation $[14,15]$, angiotensin II-induced lipolysis was ameliorated by the ARB losartan [16]. The angiotensin II type 1 and type 2 receptors are involved in determining adipocyte size $[8,17]$. Thus, the RAS in adipose tissue is closely related to adipocyte growth and function. Accordingly, angiotensin II signaling via the type 1 and type 2 receptors may regulate adipocyte particle size, and ARBs may ameliorate adipocyte dysfunction.

In this study, plasma leptin levels were higher in the candesartan group than in the control group, but adiponectin levels were similar in both groups. However, the mRNA expression levels of leptin, adiponectin, and PPAR $\gamma$ were higher in the candesartan group than in the control group.

Leptin is secreted from hypertrophic adipocytes and its circulating level is directly proportional to body fat. In terms of its roles, leptin stimulates energy consumption by activating the sympathetic nerve system and promotes fatty acid $\beta$-oxidation in peripheral tissues [18]. Plasma leptin and epididymal leptin mRNA levels were higher in the candesartan group than in the control group. This increase in leptin expression possibly contributed to the lower incidence of stroke in the candesartan-treated group. Although precise mechanisms are still unknown, leptin may protects against severe energy depletion due to

Table 2 Effects of candesartan on biological parameters in SHRSP

\begin{tabular}{llll}
\hline & $\begin{array}{l}\text { Control } \\
\text { group }\end{array}$ & $\begin{array}{l}\text { Candesartan } \\
\text { group }\end{array}$ & $\mathbf{p}$ \\
\hline Blood pressure (mmhg) & $265 \pm 5$ & $213 \pm 6$ & $<0.01^{*}$ \\
Body weight (g) & $287 \pm 8$ & $307 \pm 6$ & $<0.05^{*}$ \\
Brain weight (g) & $2.061 \pm 0.052$ & $1.897 \pm 0.023$ & $<0.05^{*}$ \\
Stroke (rats with stroke/total rats) & $7 / 8(87.5 \%)$ & $0 / 8(0 \%)$ & $<0.01 \#$ \\
Total fat pad (g) & $6.242 \pm 0.563$ & $9.344 \pm 0.338$ & $<0.05^{*}$ \\
\hline
\end{tabular}

Values are means $\pm S E$. *Student's $t$-test; \#Wilcoxon's test. lopatrophy in SHRSP. This possibility is supported by a study conducted by Avraham et al. [19], who reported that leptin administration significantly improved neurological disability and reduced infarct volume following permanent middle cerebral artery occlusion in Sebra mice. Furthermore, in clinical trials, it was reported that leptin improved insulin resistance in lipoatrophic patients $[20,21]$. Although further large-scale trials are needed to demonstrate the long-term efficacy and safety of leptin, a new drug application for leptin is anticipated [22]. To explore the therapeutic role of leptin, Ebihara et al. [23] crossed A-ZIP/F1 mice, which exhibit severe lipoatrophy, with mice overexpressing leptin in the liver. The resulting doubly transgenic mice virtually lacked adipose tissue but had elevated leptin levels. These mice showed improvements in insulin sensitivity, hepatic steatosis, and normal glucose and insulin levels [23]. These results indicate that leptin has an important role in the pathogenesis of circulatory disturbance as well as metabolic disorders.

On the other hand, the mRNA expression levels of adiponectin and PPAR $\gamma$ were also increased in the candesartan-treated group. PPARY is nuclear transcription factor in adipocytes, where it control the expression of numerous genes involved in glucose and lipid metabolism, and cell differentiation in particular [24]. Zorad et al. [8] investigated the effects of candesartan in normotensive WKY and reported marked decreases in body weight with increasing of expression of adiponectin and PPAR $\gamma$. However, the plasma leptin level and its mRNA expression in adipose tissue were lower in the candesartan group than in the control group. Their findings were generally similar to those of our present study, except for leptin expression. This difference may be due to differences in methods, including strain of rat, candesartan dose, and the duration of treatment. Nevertheless, the results of both studies are consistent in terms of the improvement in adipocyte function in candesartan-treated rats.

As described above, candesartan ameliorated adipocyte dysfunction in SHRSP, which we thought were mediated 
leptin

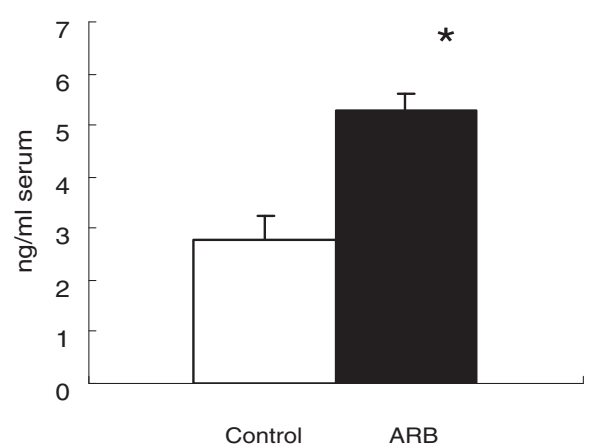

adiponectin

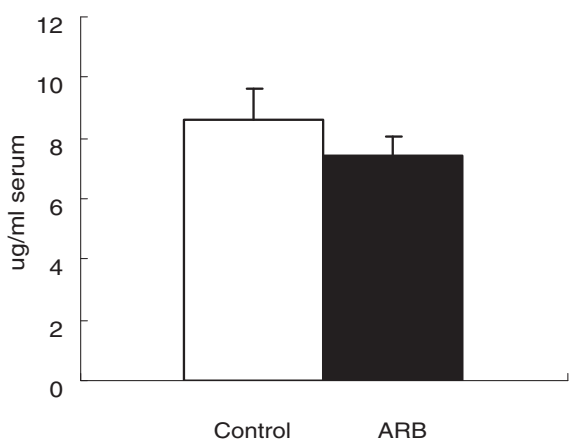

Figure 1 Effects of candesartan on plasma leptin and serum adiponectin levels. Values are means \pm SE. ${ }^{*} p<0.05$ vs. the control group.

by an increase in adiponectin production. To confirm this hypothesis, we investigated the effects of continuous intravenous infusion of recombinant adiponectin in mature SHRSP. The results of this experiment revealed an increase in plasma adiponectin levels, although the increase was not statistically significant. However, the adiponectin mRNA expression level in adipose tissue was significantly higher in the adiponectin-treated group than in the control group. On the other hand, there were no significant differences in the mRNA expression levels of leptin, Adipo-R1, AdipoR-2, or cadherin 13 between the two groups. Unexpectedly, we found no differences in body weight or blood pressure between the two groups. Bassi et al. [25] investigated the chronic effects of centrally administered adiponectin in SHR and reported that adiponectin did not appear to have an important role in long-term control of blood pressure. Thus, we and Bassi et al. [25] found no remarkable effects of adiponectin on the circulatory disturbances in SHR or SHRSP. This means that adiponectin is not a major regulator of blood pressure in essential (i.e., genetic) hypertension. However, several reports have indicated that adiponectin may lower blood pressure by regulating the nitric oxide synthetic pathway [26,27]. We did not investigate the changes in nitric oxide-related molecules in the present study.

In conclusion, we revealed the candesartan has beneficial effects not only for decreasing of blood pressure but also improvement of adipocyte dysfunction, although the

Table 3 Effects of candesartan on mRNA expression levels of adipocyte-related molecules

\begin{tabular}{llll}
\hline & Control group & Candesartan group & $\mathbf{p}^{*}$ \\
\hline Leptin & $0.17 \pm 0.02$ & $0.36 \pm 0.05$ & $<0.01$ \\
Adiponectin & $0.53 \pm 0.06$ & $0.94 \pm 0.11$ & $<0.01$ \\
PPARY & $0.11 \pm 0.02$ & $0.34 \pm 0.07$ & $<0.01$ \\
\hline
\end{tabular}

PPARY: peroxisome proliferator-activated receptor $\gamma$. Expression levels are shown as the ratio to $18 \mathrm{~S}$ rRNA. Values are means \pm SE. *Student's $t$-test. latter must be secondary to decreasing of blood pressure. Leptin may be more deeply related to decreasing of stroke as compared to adiponectin in SHRSP. Further studies are required to elucidate $t$ role of renin-angiotensin system in adipocyte in relation to hypertension and stroke.

\section{Materials and methods \\ Animals}

Male SHRSP/kpo and Wistar-Kyoto rats (WKY/kpo), as a normotensive control, were used in this study. These rats are from the original strains provided by Dr. Okamoto (Kyoto University) and were maintained at the Animal Center, Faculty of Medicine, Kinki University. All experimental protocols conformed to the guidelines of the National Institutes of Health (Guide for the Care and Use of Laboratory Animals 1996), and were approved by the Institutional Animal Experimentation Committee of Kinki University.

Table 4 Effects of intravenous adiponectin infusion in SHRSP

\begin{tabular}{lllll}
\hline & & $\begin{array}{l}\text { Control } \\
\text { group }\end{array}$ & $\begin{array}{l}\text { Adiponectin } \\
\text { group }\end{array}$ & $\mathbf{p}^{*}$ \\
\hline Blood pressure & $(\mathrm{mmHg})$ & $241 \pm 3$ & $249 \pm 7$ & $\mathrm{~ns}$ \\
Body weight & $(\mathrm{g})$ & $305 \pm 7$ & $303 \pm 8$ & $\mathrm{~ns}$ \\
Blood & & & & \\
Adiponectin & $(\mathrm{ng} / \mathrm{ml})$ & $7160 \pm 680$ & $7974 \pm 388$ & $\mathrm{~ns}$ \\
Leptin & $(\mathrm{pg} / \mathrm{ml})$ & $2593 \pm 807$ & $2331 \pm 363$ & $\mathrm{~ns}$ \\
Adipose tissue & & & & \\
Adiponectin & Ratio to 18SrRNA & $0.23 \pm 0.02$ & $0.51 \pm 0.06$ & $<0.01$ \\
Muscle & & & & \\
Adipo-R1 & Ratio to 18SrRNA & $0.97 \pm 014$ & $0.95 \pm 0.06$ & $\mathrm{~ns}$ \\
Adipo-R2 & & $0.99 \pm 0.13$ & $0.76 \pm 0.09$ & ns \\
Cadherin 13 & & $22.29 \pm 3.89$ & $16.72 \pm 1.35$ & ns \\
\hline
\end{tabular}

Adipo-R: adiponectin receptor. Values are means $\pm \mathrm{SE}$. *Student's $t$-test. 


\section{Characterization of SHRSP and WKY}

Male SHRSP and WKY were used at 6 and 20 weeks of age (6 rats in each). The biological factors (as described below), serum adipokine levels, and the mRNA expression levels of adipocyte-related genes in epididymal fat tissue were determined.

\section{Effects of candesartan administration}

Male SHRSP at 15 weeks of age were randomly divided into a control group and a candesartan-treated group (eight rats per group). Candesartan (Takeda Pharmaceutical Co. Ltd., Tokyo, Japan) was orally administered for 5 weeks from 16 weeks of age $(2 \mathrm{mg} / \mathrm{kg} /$ day $)$.

\section{Effects of adiponectin administration}

To investigate the effects of exogenous adiponectin on the pathophysiology in SHRSP, we first cloned rat adiponectin using Escherichia coli, as described below. Purified adiponectin (in phosphate-buffered saline [PBS]) was administered to five 16-week-old SHRSP for 2 weeks using an osmotic mini-pump $(100 \mu \mathrm{g} /$ day $)$. Control rats $(n=5)$ were administered PBS alone $(\mathrm{n}=5)$.

\section{Measurements}

Blood pressure and body weight was measured once weekly until 20 weeks of age. Blood pressure was measured using the tail-cuff method in conscious rats. At 20 weeks of age, blood samples were taken from the vena cava under sodium pentobarbital anesthesia. Plasma samples were prepared from blood collected in heparinized syringes by centrifugation at $6,000 \times g$ for $10 \mathrm{~min}$. Serum samples were prepared from blood collected in non-heparinized syringes by centrifugation at 10,000 $\times g$ for $10 \mathrm{~min}$. Brain and epididymal fat tissue were excised, weighed, and observed macroscopically.

\section{Molecular cloning, expression, and purification of full-length rat adiponectin}

The adiponectin gene (Adipoq, NM_144744) was amplified from cDNA prepared using the reverse primer 5'ACCCAAGCTTCAGTTGGTATCATGGTAG-3'. The resulting PCR product was digested with $\mathrm{BamHI}$ and HindIII, and then cloned into a pQE30 vector (Qiagen, Hilden, Germany), which has $6 \times$ His tag at the $\mathrm{N}$ terminus the adiponectin gene. The construct was then transformed into E. coli JM109 (New England BioLabs, Ipswich, MA, USA) and screened on Luria broth medium containing $100 \mu \mathrm{g} / \mathrm{ml}$ ampicillin (LB-Amp). The plasmid was collected from LB-Amp-screened E. coli JM109 and the Adipoq sequence was screened using an ABI PRISM ${ }^{\circ}$ 310 Genetic Analyzer (Applied BioSystems, Foster City, CA, USA).

E. coli JM109 containing the Adipoq gene were cultivated in LB-Amp at $37^{\circ} \mathrm{C}$ by inducing adiponectin protein expression with isopropyl- $\beta$-D-thiogalactopyranoside. The bacteria were harvested and stored at $-20^{\circ} \mathrm{C}$ until use. The E. coli were then solubilized with lysis buffer containing BugBuster (Takara Bio, Shiga, Japan), $100 \mathrm{mM}$ imidazole, and protease inhibitor cocktail (Sigma, St. Louis, MO, USA) in PBS ( $\mathrm{pH} 7.4$ ) at room temperature for $30 \mathrm{~min}$, followed by centrifugation at $16,000 \times g$ for $20 \mathrm{~min}$. The precipitates were collected because adiponectin protein was stored in inclusion body (data not shown). The inclusion bodies were isolated using BugBuster, and then solubilized and denatured with $2 \mathrm{ml}$ of PBS ( $\mathrm{pH} 7.4$ ) containing $7 \mathrm{M}$ guanidine- $\mathrm{HCl}$ and $1 \%(\mathrm{v} / \mathrm{v}) \alpha$-mercaptoethanol at room temperature. The denatured adiponectin was refolded by incubation in a 200-fold volume of PBS containing $2 \mathrm{M}$ urea at $4^{\circ} \mathrm{C}$ for 3 days. After concentration, the adiponectin was purified using an Ni Sepharose ${ }^{\mathrm{Tm}} 6$ Fast Flow column (GE Healthcare, Little Chalfont, UK) by eluting with PBS containing $200 \mathrm{mM}$ imidazole. The purified adiponectin was cleared of endotoxin using ActiClean Etox (Sterogene Bioseparations Inc., Carlsbad, CA, USA), concentrated, transferred to PBS, and passed through a $0.22 \mu \mathrm{m}$ filter.

\section{Analysis of adipokine levels}

Plasma leptin and serum adiponectin levels were measured using commercial enzyme-linked immunosorbent assays (B-Bridge International Inc., Cupertino, CA, USA; Otsuka Pharmaceutical Co., Ltd., Tokyo, Japan). The optical density of each sample was measured using a Bio Rad model 680 spectrophotometer (Bio-Rad Laboratories, Hercules, CA, USA).

The mRNA expression levels of leptin, adiponectin, and PPAR $\gamma$ in epididymal adipose tissue were analyzed by real-time polymerase chain reaction (RT-PCR). The expression levels of Adipo-R1, Adipo-R2, and cadherin 13 in skeletal muscle were also determined by RT-PCR. Briefly, total RNA was isolated using an RNeasy Mini Kit (Qiagen) and cDNA was synthesized using an ExScript RT reagent kit (Takara Bio). RT-PCR was performed using the SYBR Premix Ex Taq (Takara Bio) on an ABI 9700HT (Applied Biosystems) with PCR primers purchased from Takara Bio.

\section{Statistical analysis}

Statistical analysis was carried out using Student's $t$-test for blood pressure and biochemical factors. Wilcoxon's test was used for the incidence of stroke.

\section{Abbreviations}

Adipo-R: Adiponectin receptor; ARB: Angiotensin II type I receptor blocker; SHR: Spontaneously hypertensive rat; SHRSP: Stroke-prone spontaneously hypertensive rat; PPARY: Peroxisome proliferator-activated receptor $\gamma$; PBS: Phosphate-buffered saline; RT-PCR: Real-time polymerase chain reaction; RAS: Renin angiotensin system; WKY: Wistar-Kyoto rat. 


\section{Competing interests}

The authors declare that they have no competing interests.

\section{Authors' contributions}

Design of the study: HI; data collection and analysis: KT and TI; final approval of the manuscript: $\mathrm{KT}, \mathrm{TI}$, and $\mathrm{HI}$.

\section{Acknowledgements}

We thank Mrs Eiko Honda (Kinki University Life Science Research Institute) for assisting with RT-PCR and Yasumitsu Akahoshi (Kinki University Life Science Research Institute) for preparation of histopathological sections. We also thank the staff at the Animal Center, Faculty of Medicine, Kinki University for animal care.

\section{Author details}

${ }^{1}$ Department of Food Science and Nutrition, Faculty of Agriculture, Kinki University 3327-204, Nakamachi Nara-City, Nara 631-8505, Japan. ${ }^{2}$ Department of Pathology, Faculty of Medicine, Kinki University 377-2 OhnoHigashi, Osaka-Sayama, Osaka 589-8511, Japan. ${ }^{3}$ Department of Biomedical Engineering, Faculty of Biology-Oriented Science and Technology, Kinki University 930 Nishi-mitani, Kinokawa, Wakayama 649-6493, Japan.

Received: 15 May 2013 Accepted: 18 July 2013

Published: 22 July 2013

\section{References}

1. Sequra J, Ruilope LM: Obesity, essential hypertension and renin-angiotensin system. Public Health Nutr 2007, 10:1151-1155.

2. Sattler FR, Qian D, Louie S, Johmson D, Briggs W, DeQuattro V, Dube MP: Elevated blood pressure in subjects with lipodystrophy. AIDS 2001, 15:2001-2010

3. Crane HM, Grunfeld C, Harrington RD, Kitahata MM: Lipoatrophy and lipohypertrophy are independently associated with hypertension. HIV Med 2009, 10:496-503.

4. Auclair M, Vigouroux C, Boccara F, Capel E, Vigeral C, Guerci B, Lascols O, Capeau J, Caron-Debarle M: Peroxisome proliferator-activated receptor- $\gamma$ mutations responsible for lipodystrophy with severe hypertension activate the cellular renin-angiotensin system. Arterioscler Thromb Vasc Biol 2013, 33:829-838.

5. Lamounier-Zepter V, Bornstein SR, Kunes J, Zicha J, Kresk M, Ehrhanrt-Bornstein M, Ziegler CG, Kiessling A, Funk RH, Haluzik M: Adrenocortical changes and arterial hypertension in lipoatrophic A-ZIP/F-1 mice. Mol Cell Endocrinol 2008, 280:39-46.

6. Takemori K, Gao YJ, Ding L, Lu C, Su LY, An WS, Vinson C, Lee RM: Elevated blood pressure in transgenic lipoatrophic mice and altered vascular function. Hypertension 2007, 49:365-372.

7. Engeli S, Schling P, Gorzelniak K, Boschmann M, Janke J, Ailhaud G, Teboul M, Massiera F, Sharma AM: The adipose-tissue renin-angiotensin-aldosterone system: role in the metabolic syndrome? Int J Biochem Cell Biol 2003, 35:807-825.

8. Zorad S, Dou JT, Benicky J, Hutanu D, Tybitanclova K, Zhou J, Saavedra JM: Long-term angiotensin II AT1 receptor inhibition produces adipose tissue hypotrophy accompanied by increased expression of adiponectin and PPARgamma. Eur J Pharmacol 2006, 552:112-122.

9. Takemori $\mathrm{K}$, Ishida $\mathrm{H}$, Ito $\mathrm{H}$ : Continuous inhibition of the renin-angiotensin system and protection from hypertensive end-organ damage by brief treatment with angiotensin II type 1 receptor blocker in stroke-prone spontaneously hypertensive rats. Life Sci 2005, 77:2233-2245.

10. Hamaguchi R, Takemori K, Inoue T, Masuno K, Ito H: Short-term treatment of stroke-prone spontaneously hypertensive rats with an AT1 receptor blocker protects against hypertensive end-organ damage by prolonged inhibition of the renin-angiotensin system. Clin Exper Pharmacol Physiol 2008, 35:1151-1155.

11. Nishimura Y, Ito T, Saavedra JM: Angiotensin II type 1 blockade normalizes cerebrovascular autoregulation and reduces cerebral ischemia in spontaneously hypertensive rats. Stroke 2000, 31:2478-2486.

12. Ito T, Nishimura Y, Saavedra JM: Pre-treatment with candesartan protects from cerebral ischemia. J Renin Angiotensin Aldosterone Syst 2001, 2:174-179.

13. Yamakawa $H$, Jezzova $M$, Ando $H$, Saavedra JM: Normalization of endothelial and inducible nitric oxide synthase expression in brain microvessels of spontaneously hypertensive rats by angiotensin II AT1 receptor inhibition. J Cereb Blood Flow Metab 2003, 23:371-380.

14. Janke J, Engeli S, Gorzelniak K, Luft FC, Sharma AM: Mature adipocytes inhibit in vitro differentiation of human preadipocytes via angiotensin type 1 receptors. Diabetes 2002, 51:1699-1707.
15. Massiera F, Bloch-Faure M, Ceiler D, Murakami K, Fukamizu A, Gasc JM, Quignard-Boulange A, Negrel R, Ailhaud G, Seydoux J, Meneton P, Teboul $\mathrm{M}$ : Adipose angiotensinogen is involved in adipose tissue growth and blood pressure regulation. FASEB J 2001, 15:2727-2729.

16. Cabassi A, Coghi P, Govoni P, Barouhiel E, Speroni E, Cavazzini S, Cantoni AM, Scandroglio R, Fiaccadori E: Sympathetic modulation by carvedilol and losartan reduces angiotensin II-mediated lipolysis in subcutaneous and visceral fat. J Clin Endocrinol Metab 2005, 90:2888-2897.

17. Yvan-Charvet L, Even P, Bloch-Faure M, Guerre-Millo M, Moustaid-Moussa N, Ferre $P$, Quignard-Boulange A: Deletion of the angiotensin type 2 receptor (AT2R) reduces adipose cell size and protects from diet-induced obesity and insulin resistance. Diabetes 2005, 54:991-999.

18. Shimabukuro M, Koyama K, Chen G, Wang MY, Trieu F, Lee Y, Newgard CB, Unger $\mathrm{RH}$ : Direct antidiabetic effect of leptin through triglyceride depletion of tissues. Proc Natl Acad Sci USA 1997, 94:4637-4641.

19. Avraham Y, Davidi N, Porat M, Chernoguz D, Magen I, Vorobeiv L, Berry EM, Leker RR: Leptin reduces infarct size in association with enhanced expression of CB2, TRPV1, SIRT-1 and leptin receptor. Current NeurovasC Res 2010, 7:136-143.

20. Oral EA, Simha V, Ruiz E, Andewelt A, Premkumar A, Snell P, Wagner AJ, DePaoli AM, Reitman ML, Taylor SI, Gorden P, Garg A: Leptin-replacement therapy for lipodystrophy. N Engl J Med 2002, 346:570-578.

21. Ebihara K, Masuzaki $H$, Nakao K: Long-term leptin-replacement therapy for lipoatrophic diabetes. N Engl J Med 2004, 351:615-616.

22. Brennan AM, Mantzoros CS: Drug insight: the role of leptin in human physiology and pathophysiology-emerging clinical applications. Nat Clin Pract Endocrinol Metab 2006, 2:318-327.

23. Ebihara K, Ogawa Y, Masuzaki H, Shintani M, Miyanaga F, Aizawa-Abe M, Hayashi T, Hosoda K, Inoue G, Yoshimasa Y, Gavrilova O, Reitman ML, Nakao K: Transgenic overexpression of leptin rescues insulin resistance and diabetes in a mouse model of lipoatrophic diabetes. Diabetes 2001, 50:1440-1448.

24. Trayhurn P, Beattie JH: Physiological role of adipose tissue: white adipose tissue as an endocrine and secretory organ. Proc Nutr Soc 2001, 60:329-339.

25. Sharma AM, Janke J, Gorzelniak K, Engeli S, Luft FC: Angiotensin blockade prevents type 2 diabetes by formation of fat cells. Hypertension 2002, 40:609-611.

26. Ardiansyah H, Shirakawa H, Koseki T, Hiwatashi K, Takahasi S, Akiyama Y, Komai M: Novel effect of adenosine 5'-monophosphatase on ameliorating hypertension and the metabolism of lipoids and glucose in stroke-prone spontaneously hypertensive rats. J Agri Food Chem 2011, 59:13238-45.

27. DeClercq V, Taylor CG, Wigle J, Wright B, Tworek L, Zahradka P: Conjugated linoleic acid improve blood pressure by increasing adiponectin and endothelial nitric oxide synthase activity. J Nutr Biochem 2012, 23:487-93.

\section{doi:10.1186/1476-511X-12-108}

Cite this article as: Takemori et al:: Effects of Angiotensin II Type 1 receptor blocker and adiponectin on adipocyte dysfunction in strokeprone spontaneously hypertensive rats. Lipids in Health and Disease 2013 12:108.

\section{Submit your next manuscript to BioMed Central and take full advantage of:}

- Convenient online submission

- Thorough peer review

- No space constraints or color figure charges

- Immediate publication on acceptance

- Inclusion in PubMed, CAS, Scopus and Google Scholar

- Research which is freely available for redistribution 